\title{
Legal Protection on Workers' Unilateral Wages Deductions Due to the Covid-19 Pandemic
}

\author{
Suherman ${ }^{1}$; Alda Damayanti Putri ${ }^{2}$ \\ ${ }^{1}$ Law Faculty of UPN Veteran Jakarta, Indonesia \\ ${ }^{2}$ Student of Magister of Law UPN Veteran Jakarta, Indonesia \\ http://dx.doi.org/10.18415/ijmmu.v7i10.2157
}

\begin{abstract}
In 2020, the presence of the Covid-19 Virus has had an impact on many sectors in human life. The impact of this virus is not only on the health sector but also spreads to the economic sector, especially business. The difficulty of business activities in Indonesia amid the Covid-19 pandemic has caused many companies to decide to cut the wages of their workers. However, problems arise when several companies violate the rights of their workers by unilaterally cutting workers' wages which are not in accordance with the existing regulations in Law no. 13 of 2003 concerning Manpower, Government Regulation no. 78 of 2015 concerning Wages, and more specific regulations in the midst of a pandemic through the Minister of Manpower Regulation No. M/3/HK.04/III/2020 concerning Protection of Workers/Laborers and Business Continuity in the Context of Prevention and Overcoming Covid-19. This research uses empirical normative method. In normative research, the type of data used was secondary data, which consisted of primary, secondary and tertiary legal materials. While empirical research, using primary data in the form of answers that could be obtained in the field. The specific objective that will be achieved in this research is how to protect the law against workers who cut wages to their workers.
\end{abstract}

Keywords: Legal Protection; Deduction of Wages; Workers

\section{A. Introduction}

The Covid-19 virus that emerged in early 2020 has changed the life order of the world community. The reason is, the presence of Covid-19 has become a challenge for the whole world in all sectors of life. Covid-19 was first discovered and identified in the Wuhan, China, by the authorities as the new Coronavirus in early January 2020. Five days later, the Chinese Government reported the first case of its citizen's death after being infected with Covid-19 (kompas.com, 12 March 2020). Not only that, the Covid-19 virus then began to spread to many countries. This virus was declared a pandemic by the Director General of WHO, Tedros Adhanom Ghebreyesus on March 11, 2020 after being identified as having infected 121,564 people in 118 countries based on data from John Hopkins (cnnindonesia.com, March 12, 2020). 
The Covid-19 pandemic has caused global economic shocks. According to Warwick McKibbin and Roshen Fernando (2020), the Covid-19 pandemic has a significant impact on the global economy in the short term (quoted from Taufik and Ayuningtias, 2020). The Covid-19 pandemic has also caused an economic recession globally. According to the analysis, the continuous spread causes a decline in growth of between $0.3 \%-0.7 \%$ in global gross domestic product (GDP) in 2020. In addition, this pandemic also resulted in a decrease in demand between $1.8 \%-2,2 \%$ which also slows down global economic growth. Sectors that have experienced a decline in demand are the tourism, hospitality, aviation and goods sectors (Hua and Shaw, 2020).

In Indonesia, Corona virus cases were announced on March 2, 2020 by the President of Indonesia, Joko Widodo (kompas.com, March 3, 2020). This was followed by local lockdowns in several areas in Indonesia such as Tegal, Papua and DKI Jakarta to limit direct meetings or physical contact (kompas.com, March 29, 2020). In the capital city of Indonesia, DKI Jakarta, which is also known as the center of business operations, has imposed large-scale social restrictions (PSBB) and work from home (WFH) with the issuance of the Governor of the Special Capital Region of Jakarta No. The Spread of the Coronavirus Disease (Covid-19) Outbreak (Jdih Jakarta, 2020). Based on the DKI Jakarta Manpower and Transmigration Office (2020), there are 3,290 companies in Jakarta that implement the WFH system (quoted from Taufik and Ayuningtias, 2020).

The large-scale social restrictions (PSBB) policy taken by the DKI Jakarta government and other regions of Indonesia is an effort to reduce the spread of Covid-19 which it is feared will have a more negative impact in the future if it is not controlled. But on the other hand, the implementation of this large-scale social restrictions (PSBB) directly impacts activities in the business sector and society in Indonesia (Taufik and Ayuningtias, 2020). Some companies that feel the impact of the implementation of these government policies are forced to reduce the salaries of their workers or even terminate their work relations (layoffs) and even worse close their companies (Huwaidah, 2020).

The economy is a unified circular flow consisting of the consumer and producer societies. In simple terms, the expenditure of one entity is sustenance for another. The production of one entity is not only ready-to-consume goods and services, but also income for households working in factories and production households. ${ }^{1}$ (Wanda Ayu 2020) Thus the production, marketing and purchasing processes stop. The economy wheel cannot spin as fast as it did before the Lock Down.

Indonesia does not take a total lockdown policy. The strategy adopted by the Indonesian government is Large-Scale Social Restrictions (PSBB). This decision was conveyed by President Joko Widodo during a limited meeting at the State Palace on March 30, 2020. In fact, the terms lockdown or large-scale social restrictions are both regulated in the Health Quarantine Law Number 6 of 2018. Both are risk factors mitigation in areas in a Public Health Emergency. ${ }^{2}$ (Redaksi Kumparan 2020). But, in this paper we will not discuss in detail the differences between large-scale social restrictions (PSBB) and Lock Down.

In the face of a lock down and an economic slowdown, many companies have adopted a strategy to tighten their belts. Efficiency of cash flow is carried out in order to survive in a situation with uncertainty. Some of the efficiency alternatives taken by the company have made a work from home policy to cut wages and even layoffs. The excuse of efficiency is the main reason for this policy. Force majeure is used as the basis for the company to cancel the work agreement made between the company and the employee. Departing from this issue, an interesting thing that can be discussed is the view from a legal point of view about the validity of employee salary deductions whether it is allowed that the

\footnotetext{
1 Wanda Ayu. (2020, March 26). Universitas Indonesia. Retrieved from https://www.ui.ac.id/rektor-ui-memahami-dampaklockdown-bagi-perekonomian-indonesia/

${ }^{2}$ Redaksi Kumparan. 2020. Kumparan. March 30. https://kumparan.com/kumparannews/arti-psbb-yang-ditetapkan-jokowi-danperbedaan-dengan-lockdown-1t7s6Hq9P7k/full.
} 
company deduct employee salaries against their employees under the pretext of force majeure during COVID 19.

\section{B. Research Methods}

This journal uses normative legal research methods or doctrinal legal research. Normative legal research is a prescriptive research that describes law through the views that exist in its norms. In Indonesia, normative legal research tends to be oriented towards practical aspects, it is the resolution of certain legal problems carried out by legal practitioners either in a dispute or in other matters to explore where and how legal disputes are regulated in law carried out by researchers by researching legal facts, legal cases, and legal regulations that are concerned or relevant to the question to be resolved. Whereas empirical research is empirical research is also needed, including field research is also needed to find out how do companies cut salaries for their workers and cases that occur as a result of companies cutting their workers' salaries.

\section{Discussion}

In Indonesia, the Covid-19 pandemic has caused various problems in many sectors, especially the business and trade sectors. The Large-Scale Social Restrictions (PSBB) and WFH policies implemented by both the central and local governments have a direct impact on business activities in Indonesia. The difficulty of companies in obtaining raw materials for production, where there are still many Indonesian companies partnering with China in the supply of raw materials, while in the midst of this pandemic China has closed many of its ports causing limited availability of production supplies for companies in Indonesia. In addition, due to limited supply availability, companies are still unable to increase the prices of their products because of low purchasing power and public demand (accurate digital partner news, April 14, 2020).

During the Covid-19 pandemic, many entrepreneurs were under economic and social stress. The crisis which started in the health sphere has spread to the economic sphere. The declining economic power affected many parties, including companies and workers. Many of the companies in Indonesia in the midst of this pandemic are facing a crisis that makes them have to make the best decisions and solutions for companies and workers (Anwar, 2020).

There are many challenges that companies in Indonesia have to face in the midst of the Covid-19 pandemic. The first challenge is the extension of the WFH period which will have an impact on the performance of workers and companies that are less effective. The implementation of WFH causes a lack of collaboration and communication between divisions which leads to a lack of employee productivity and slow company performance. The second challenge is disruption of production. As previously explained, there are still many Indonesian companies partnering with China in supplying raw materials for production, however, because the Covid-19 virus originated in China and currently many ports in China are closed, this has an impact on the limited supply of materials. production standards for companies in Indonesia. In addition, the decline in people's purchasing power causes companies to be unable to increase the selling price of their products (accurate.partners, April 14, 2020).

Lack of public demand and the implementation of Work From Home (WFH) for workers reduces the effectiveness of running a business in Indonesia which at the same time causes companies to experience a lack of income. This then leads to policies taken by companies to reduce their expenses in one way, it is cutting workers' wages (accurate digital partner news, April 14, 2020). In Indonesia, the procedure for cutting wages for employees by companies is regulated in Law no. 13 of 2003 concerning Manpower, Government Regulation no. 78 of 2015 concerning Wages, and more specific regulations in 
the midst of a pandemic through the Minister of Manpower Regulation No. M/3/HK.04/III/2020 concerning Protection of Workers/Laborers and Business Continuity in the Context of Prevention and Overcoming Covid-19.

In Law number 13 of 2003 concerning Manpower, article 1 paragraph 21 is a collective working agreement is an agreement which is the result of negotiations between a trade union/labor union or several trade unions/labor unions registered with the agency responsible for manpower affairs and the entrepreneur, or several entrepreneurs or employers' associations which contain the terms of work conditions, rights and obligations of both parties. Here applies the principle of lex specialis derogate lex generalis. Law Number 13 Year 2003 which specifically regulates employment overrides Chapter VIIIA of the Civil Code regarding work agreements.

While the elements that must be contained in a work agreement are those that are still in Law 13 of 2003 paragraph 15 . Work relations are the relationships between entrepreneurs and workers/laborers based on work agreements, which have elements of work, wages, and orders. Thus, in general the work agreement must contain and regulate the main duties and functions or job descriptions of workers within a certain time frame along with the chain of command from which workers receive orders and provide reports including the salaries or wages and benefits that workers will receive in connection with his job.

Before the Collective Labor Agreement or Company Regulations are agreed and signed by both parties, especially by employees, there must be a socialization of the contents of the agreement. Both parties must understand before signing the agreement. Furthermore, the agreement should be made without coercion by any party. Although signing by coercion is not an element that must be fulfilled by both parties, it is necessary to remember that there are three foundations or principles of legal formation, they are: the principle of justice, the principle of benefit and the principle of legal certainty.

An agreement can be equated with legislation which is limited only to the two parties. Based on the principle of freedom of contract in article 1338 of the Civil Code, the parties to the contract are free to enter into an agreement, whatever the content or form: "All agreements made legally apply to the law for those who make it."' (Rachmadsyah 2010)

In the work agreement between the company and the employee, the salary is also agreed, usually the salary is based on the competence of an employee. Elements in the minimum competency meet the requirements for Knowledge, Skill and Attitude. Generally, higher competency is directly proportional to the salary or wages paid by the employer. Salaries are limited by the time dimension as a payment framework. For example, there is a salary that is paid every hour. Some are paid daily or every week. In Indonesia, it is common for salaries to be paid each month. Working hours are also regulated in the Manpower Act number 13 of 2003 articles 77 to 79 . The amount of salary or wages should be regulated and stated in the work agreement agreed upon by both parties including the amount and time frame as well as the scope of work so as not to cause "Dispute" in the following day.

In the current state of the Covid-19 pandemic, the phrase force majeure is often heard recently. The language of force majeure is taken from French. "Force" means "Strength" while "Majeure" means "Main" or "Great", so force majeure is a large force that is unknown or predictable by the parties making the agreement. In positive law in Indonesia, there is no law that specifically regulates or defines force majeure. However, implicitly, the Civil Code has alluded to this in Book 3 Articles 1244 and 1245 by using the terms "something unexpected" and "a compelling situation or because of things that happen by

\footnotetext{
${ }^{3}$ Rachmadsyah, Shanti. 2010. Hukum Perjanjian. August 3.

https://www.hukumonline.com/klinik/detail/ulasan/lt4c3d1e98bb1bc/hukum-perjanjian/.
} 
chance". Here, there is a gap between das sollen and das sein. There is no lex specialis that specifically regulates Force Majeure. However, Civil Code Book 3 articles 1244 and 1245 are the closest to being a reference to legislation related to Force Majeure.

In practical use, force majeure can be called as forcing circumstances where there are events categorized as conditions that bring consequences to the parties in an engagement, in which the party who cannot fulfill the performance is not declared in default. ${ }^{4}$ (Rasuh February 2016)

Returning to the Civil Code, based on these provisions, the main elements that can cause a force majeure are: ${ }^{5}$ (Harnowo 2020) it is an unexpected event; there are obstacles that make an achievement impossible; The inability is not caused by the debtor's mistake and the inability cannot be borne by the risk of the debtor. In general, this situation is aimed at physical and legal performance, not only due to difficulties in carrying out obligations. Mieke Komar Kantaatmadja shares the following similar view: ${ }^{6}$ (Isradjuningtyas 2015)

1. Changes in a situation did not exist at the time when the agreement was formed.

2. The changes are fundamental to the agreement.

3. The changes cannot be predicted in advance by the parties.

4. The result of the change must be radical, thus changing the scope of the obligations that must be carried out according to the agreement.

5. The use of this principle cannot be applied to border agreements as well as changes in circumstances resulting from violations committed by the party submitting the claim.

Force majeure can be divided into two categories, absolute force majeure and relative force majeure with the following explanation

1. Absolute force majeure occurs when the obligation really cannot be carried out completely, for example when objects are destroyed due to natural disasters. In this case, it is impossible to fulfill the achievement by anyone or everyone ${ }^{7}$ (Badrulzaman 1983)

2. Relative force majeure occurs when an agreement is still possible to implement but at a very large sacrifice or expense from the debtor, ${ }^{8}$ (Badrulzaman 1983)

As mentioned above, the Indonesian government has indeed not taken the Lockdown step in dealing with the COVID 19 Pandemic. Large-scale Social Restrictions or PSBB are taken as a middle way in dealing with the COVID 19 Pandemic. Through Government Regulation number 21 of 2020, it is stated that:

1. Large-scale social restrictions include at least:

a. school and work vacations;

b. restrictions on religious activities; and/or

c. restrictions on activities in public places or facilities.

2. Limitation of activities as referred to in paragraph (1) letters a and b must still take into account the needs of education, work productivity and worship of the population.

3. Limitation of activities as referred to in paragraph (1) letter $\mathrm{c}$ shall be carried out by taking into account the fulfillment of basic needs of the population.

\footnotetext{
${ }^{4}$ Rasuh, Daryl John. February 2016. "KAJIAN HUKUM KEADAAN MEMAKSA (FORCE MAJEURE) MENURUT PASAL 1244 DAN PASAL 1245 KITAB UNDANG-UNDANG HUKUM PERDATA, /Feb/2016." Lex Privatum Vol. IV/No. 22.

${ }^{5}$ Harnowo, Tri. 2020. Wabah corona sebagai alasan Force Majeure dalam perjanjian. March 30. https://www.hukumonline.com/klinik/detail/ulasan/lt5e81ae9a6fc45/wabah-corona-sebagai-alasan-iforce-majeur-i-dalamperjanjian/.

${ }^{6}$ Isradjuningtyas, Agri Chairunisa.2015."Force Majeure (Overmacht) Dalam Hukum Kontrak (Perjanjian)." Jurnal.Unpar.ac.id 5.

${ }^{7}$ Badrulzaman, Mariam Darus. 1983. KUH Perdata Buku III: Hukum Perikatan dengan Penjelasan. Alumni.

8 ibid
} 
DKI Jakarta as a business, economic and social center in Indonesia has started implementing the Large-scale Social Restrictions (PSBB) since April 9, 2020. Through Governor Regulation number 33 of 2020, Large-scale Social Restrictions (PSBB) limits citizen activities including activities at schools and/or educational institutions, Work Activities at Work, Religious Activities at Worshipping Place, Activities in Public Places, Social and Cultural Activities and Use of Transportation Modes for the Movement of People and Goods. However, it is exempted for the business sector as regulated in the Governor Regulation above, it is: all government offices/agencies, both central and regional based on regulations from the relevant ministries; Representative offices of foreign countries and/or international organizations in carrying out diplomatic and consular functions and other functions in accordance with the provisions of international law; State/Regional Owned Enterprises participating in the handling of Corona Virus Disease (COVID-19) and/or in meeting the basic needs of the community following the regulations of the relevant ministries and/or the Provincial Government of DKI Jakarta.

Despite all the activity restrictions, for some industries and educational institutions, if possible, supported by sufficient information technology resources, working or studying from home using online methods is possible. The term that is often used is Working From Home or Study From Home so that work and school activities continue and it is hoped that productivity targets can be achieved.

Thus, getting the COVID 19 pandemic is categorized as a force majeure. In simple terms, based on the definitions and categories described above, the COVID-19 Pandemic can be categorized as a Relative Force Majeure. This is because the elements contained in the Civil Code Book 3 Articles 1244 and 1245 are fulfilled. However, achievements can still be fulfilled because they can be done online as long as the resources for doing online work are available.

Regarding the reduction of wages during the Covid-19 pandemic, Law number 13 of 2003 on Manpower can be a legal reference for this matter. More specifically, Government Regulation number 78 of 2015 concerning Wages article 57 regulates wage deductions. In general, based on PP 78/2015, wages can be deducted in the following conditions:

1. Due to a reason that has become the agreement agreed in the work agreement, for example fines, compensation and/or down payment.

2. If due to things that are not regulated in the Work Agreement, it must be done based on a written agreement.

3. The deduction of wages by the employer for a third party can only be done if there is a power of attorney from the worker.

Especially during the COVID-19 pandemic, the Minister of Manpower issued a Circular Letter number M/3/HK.04/III/2020 concerning Worker/Labor Protection and Business Continuity in the Context of Prevention and Overcoming COVID 19, especially part II point 4, requiring that if there are activity restrictions business activities due to government policies, changes in the amount and payment of wages must be through an agreement between the entrepreneur and the worker.

In a case study, a company PT ABC is engaged in services with around 100 employees. The established Company Regulations have been socialized and approved and signed by employees at the time of their initial employment. The Company Regulations have regulated matters including wages and working hours as well as rights and obligations. However, the matter of force majeure has not been discussed in the Company Regulations.

At the start of the COVID-19 Pandemic, the company was still operating as usual. However, when the PSBB policy was enacted, company operations in the office were abolished, and the employees work from home by online. In general, the company's wheels and cash flow have not changed much. Services can be provided online; client needs and requirements can be met. Revenue has indeed decreased slightly, but this is due to unpaid receivables. The client asks for a delay in payment for services rendered. 
On the basis of reduced revenue, a discourse has emerged for efficiency in the form of reducing employee salaries. The company management communicates this to the union before making a policy. The basis for consideration taken by company management is the COVID-19 pandemic force majeure so that payroll agreements can be changed during the COVID-19 pandemic. Discussions between trade unions and company management have been carried out but no agreement has been found so that salary cuts are not implemented.

Meanwhile, another case of salary deductions occurred at PT. Bintang Inti Karya in Magetan, and PT Net Mediatama Televisi in Jakarta, as follows:

\section{PT. Bintang Inti Karya}

In the midst of the Covid-19 pandemic, thousands of employees of PT Bintang Inti Karya in Magetan held demonstrations. This demonstration was held on March 24, 2020 as a form of employee frustration because their wages were cut $50 \%$ without notification from the company. Not only that, the company is also late in paying the salaries of its employees. According to information from one of the employees, employee salaries are usually paid every 1st day of the month, but until almost entering the following month the salaries of employees have not been paid (news.detik, March 24, 2020).

The case of unilaterally cut wages and late payment of salaries by PT Bintang Inti Karya has violated the rights of workers as stated in Law no. 13 of 2003 Article 1 Paragraph (30) states that workers are required to receive the right to wages in the form of money for the work they have done which is given by employers and paid based on a work agreement (JDIH BPK RI, 2017). Based on the statement of Rudy Harsono, Head of the Magetan Manpower Office (Disnaker) that the salary system at PT. Bintang Inti Karya is based on work results (nusadaily.com, 25 March 2020), then, it is the right of workers to get their salary for the work they do based on a work agreement as regulated in laws and regulations and the government.

In addition, the deductions made by the company are also not in accordance with the provisions allowing the company to deduct employee salaries as stated in PP. 78 of 2015 Article 57 which states that companies may deduct workers' salaries to a maximum of $50 \%$ of wages due to fines, compensation, down payments for wages, worker debts to companies, or leasing of company goods by workers (JDIH Kemnaker, 2020). Whereas the fact is, employees whose salaries are cut not because they have debt or rent company property, but are cut because of the company's economic difficulties in the midst of the pandemic.

The company argued that the Covid-19 pandemic had made it difficult to export and import underwear produced by the company, so that the company experienced a decrease in income. This decrease in income has caused delays and unilaterally cut wages for employees (kompas.com, March 25, 2020). In handling this case, the Regent of Magetan, Suprawoto, came to help carry out the negotiations between the company and employees, and the results of the negotiations were as follows: a) The local government will pay the shortage of wages that have become the rights of the workers; b) The company will directly communicate with the local government regarding the issue of paying employee salaries which is only half of what is determined (kompas.com, March 25, 2020).

\section{PT Net Mediatama Televisi}

Since the opening of the LBH Pers Complaint Post and the Alliance of Independent Journalists AJI Jakarta on April 3, 2020, there have been 111 complaints reports in the media industry regarding employment caused by the Covid-19 pandemic. The complaints received started from salary cuts to unilaterally layoffs by the company. One of the many complaints is the unilateral cut in half of salaries and the housing of 37 employees of PT Net Mediatama Televisi (VOA, 8 August 2020). 
These employees were immediately given a decision letter to cut wages in half and layoffs by the company without any discussion and prior notification. There is no notification when they would be reinstated. Through this case, PT Net Mediatama Televisi have violated the rights of workers as stipulated in Law no. 13 of 2003, PP. 78 of 2015, and the Minister of Manpower Circular Letter No M/3/HK.04/III/2020 which of all the provisions regarding the deduction of workers' wages that have been regulated in these regulations must be based on an agreement and mutual agreement of both parties, not just one parties only. In this case, negotiations were carried out between NET management and employees and assisted by the DKI Manpower and Transmigration Office, unfortunately, the company only issued two options for its employees, they are dismissal or resigning with a certain amount of compensation money (VOA, August 8, 2020).

Actually, violations of workers' rights that have been committed by companies either PT. Bintang Inti Karya and PT Net Mediatama Televisi should receive sanctions as regulated in Law no. 13 of 2003 Article 95 Paragraph (2) states that employers who deliberately or negligently cause late payment of workers' wages are subject to fines based on a certain amount of workers' wages (JDIH BPK RI, 2017). Administrative sanctions against companies that violate workers' rights are also regulated in PP. 78 of 2015 Article 53 states that employers or workers who violate a work agreement due to intent or negligence will be subject to a fine, and it is also explained in Article 59 Paragraph (1) point d that employers who do not pay workers' wages past a certain period will be subject to administrative sanctions by the government (JDIH Ministry of Manpower, 2020). But seeing this abnormal condition, Minister of Manpower Ida Fauziah still has not determined the right sanctions for companies that cut their workers' wages, and for the time being, they are still collecting the aspirations given by workers and companies that will become policies later (finance. Sec, April 2, 2020).

In the two cases above, the root of the problem is the failure to maintain good communication between the company and employees. It must be understood that on the one hand, companies have no other choice but to decide to cut wages and delay payment of employee salaries because it can also be seen that companies in the midst of this pandemic or it can be said that in the midst of this abnormal condition are in a vulnerable and squeezed position. the economy. However, on the other hand, the company remains guilty of rights violations committed against workers. The company should have followed the correct procedure for deducting workers' wages based on the applicable law and not arbitrarily cutting and postponing employee salary payments without any agreement, notification and communication.

The theoretical approaches that can be used in the case of unilaterally cutting workers' salaries in the midst of the Covid-19 pandemic are theories of justice and theories of legal protection. In the theory of justice developed by Aristotle, a country must lead to good that can be seen through justice and truth. This justice means that everyone in a country has the same rights or obtains the same rights (J.H. Rapar, 1991: 82) (quoted from Nasution, 2014). The concept of justice according to Aristotle in this theory is divided into two, they are: distributive and commutative justice. Distributive justice is justice that emphasizes the rights that everyone gets proportionately or in another sense everyone gets what is due to him. Meanwhile, commutative justice emphasizes the establishment of fair rights among humans who are equal both physically and non-physically (Nasution, 2014).

In connecting the theory of justice with the case of unilaterally cutting workers' wages in the midst of the Covid-19 pandemic, it can be seen that in the theory of justice it has been emphasized about obtaining equal rights for everyone in a country, which in this case, the workers who should receive the right to wages paid by the company for the work they have done, they do not get these rights. The absence of workers' rights shows that justice for everyone has not been achieved. However, in resolving this case, both government and community institutions are trying to provide legal protection and justice to workers whose rights have been violated by the company with legal assistance and assistance in paying workers' salaries which have become the rights of workers. From this, both the government and community institutions strive to fulfill workers' rights and justice appropriately. 
In addition, the theory of legal protection developed by Satjipto Raharjo is an effort to regulate the interests of society to avoid overlapping interests and to enjoy the rights provided by law. This arrangement is carried out by giving limits to certain interests and giving measured power to others. Legal protection in this theory is divided into two, they are: preventive legal protection which aims to prevent a dispute from occurring; and repressive legal protection aimed at resolving a dispute (Nola, 2016).

To link the theory of legal protection with the case of unilaterally cutting workers' salaries in the midst of the Covid-19 pandemic, it can be seen that legal protection for workers has also been regulated in Law No. 13 of 2003, PP. 78 of 2015, and Circular Letter of the Minister of Manpower No. M/3/HK.04/III/2020 which explain the rights that workers can enjoy, such as payment of salaries, allowances, and the right to rest, and also highlight the sanctions given to companies which violates the rights of its workers. Although in the case that occurred in the midst of the Covid-19 pandemic, the government has not been able to impose sanctions in accordance with the laws and regulations for companies that violate their workers' rights due to abnormal conditions, however, as stated in the Preamble to the Constitution of the Republic of Indonesia In 1945, paragraph 4 states that the state is obliged to provide protection for Indonesian citizens (Nola, 2016), so in this case, the role of the government and community institutions as a mediator in finding the best solution for workers so that their wage rights can be fulfilled is wrong. one way of providing protection for workers as Indonesian citizens.

In Law no. 13 of 2003 concerning Employment (JDIH BPK RI, 2017), Article 1 paragraph 30 explains that: "Wages are the rights of workers/laborers that are received and expressed in the form of money as compensation from employers or employers to workers/laborers who are determined and paid. according to a work agreement, agreement, or statutory regulation, including allowances for workers/labor and their families for a job and/or service that has been or will be performed."

From the contents of Article 1 paragraph 30 above, it is known that every worker who has done work must receive a wage from the employer or entrepreneur as compensation for work that has been carried out based on an agreement, work agreement, and laws and regulations. Meanwhile, if an employer or employer does not pay the workers 'wages, the procedure for paying wages is also regulated in the same Law in Article 93 which contains:

"Workers' wages are not paid if the workers do not perform their work (Article 93 paragraph (1))." The provisions in paragraph (1) above do not apply to workers who: Sick so that they cannot do their job, are sick on the first and second day of menstruation, marriage, circumcise or baptism, their wives give birth or have a miscarriage, husband or wife or children or daughter-in-law or parents or parents-in-law or family members in the same household pass away, and so on.

Based on the contents of Article 93 paragraph (1), it can be interpreted that workers will not receive wages or pay if they do not perform the work agreed upon in the work agreement by employers and workers (no work no pay), however, it needs to be underlined that there are exceptions toward Article 93 paragraph (1). This exemption is regulated in Article 93 paragraph (2) as previously described (Wati, Budiono, Hitaningtyas, 2015). The provisions in Article 93 paragraph (2) must be implemented with a provision based on a work agreement, company regulations or a collective working agreement or in another sense it must be carried out based on the agreement of both parties.

In addition to the wage procedure, the Manpower Law also describes the rules regarding sanctions for violations committed by both workers and employers as stated in Article 95, as follows: Violations committed by workers due to intent or negligence can be subject to fines (Article 95 Paragraph (1)), Violations committed by employers due to intentional or negligent cause of late payment of wages are subject to fines based on a certain amount of workers' wages (Article 95 Paragraph (2)). The government regulates the fine for the employer/employee in the case of wage payment (Article 95 Paragraph (3)), In the event that a company goes bankrupt in accordance with the prevailing laws and regulations, the rights and wages of the workers are debts that must be prioritized for payment (Article 95 Paragraph (4)). 
It can be seen in Article 95 above that each worker and employer who does not carry out his obligations in accordance with the work agreement will receive their respective sanctions. In addition, when a company goes bankrupt, the worker's wages are the main thing that takes precedence over payment.

Furthermore, the procedure for paying workers' wages is also regulated in Government Regulation no. 78 of 2015 concerning Wages as stated in Articles 53, 57, 58, and 59 (JDIH Kemnaker, 2020). Article 53 explains that: "Employers or Workers/Laborers who violate the provisions of the Work Agreement, Company Regulation, or Collective Bargaining Agreement because of their deliberate intent or negligence are subject to fines if it is expressly regulated in the Work Agreement, Company Regulation, or Collective Bargaining Agreement."

Then, Article 57 also regulates the provisions for allowing wages to be deducted by the employer, as follows: The deduction of wages is made by the employer based on the work agreement, company regulations, or collective working regulations, for (Article 57 paragraph (1)): Fines; Compensation; Advances for wages. The deduction of wages is made by the employer based on an agreement or written agreement, for (Article 57 paragraph (5)): Payment of debts of workers; Rent of houses and/or company property that are rented by the employer to workers.

Meanwhile, Article 58 of this Government Regulation explains that employers can only deduct workers' wages by a maximum of 50\% (fifty percent) of the total payment of workers' wages, and for wage providers who violate the provisions of the procedure for paying workers' wages, they will be given sanctions in accordance with those stated in Article 59, which in paragraph (1) explains that employers will be subject to administrative sanctions if they do not pay religious holiday allowances to workers; does not provide workers with service fees in certain businesses; does not regulate the wage scale and structure and does not inform workers; does not pay the workers' wages until it has passed the stipulated period; not paying the fines imposed because the entrepreneur violates the work agreement, company regulations or collective agreement; and deduct workers' wages by more than $50 \%$ (fifty percent) of the paid wages received.

Article 59 paragraph (2) explains the administrative sanctions given to entrepreneurs who do not comply with the provisions in paragraph (1) in the form of a written warning; limited business activities; all means of production are temporarily suspended; and business activities are frozen. It can be interpreted from Article 59 that the wage provider cannot act arbitrarily in the payment of the wages of his workers. Employers will receive sanctions if the payment of wages is not in accordance with the work agreement, agreement, and the applicable laws.

In addition, in connection with the Covid-19 pandemic which had a negative impact on business in Indonesia, on March 17, 2020, the Minister of Manpower of the Republic of Indonesia issued Circular Letter Number M/3/HK.04/III/2020 concerning Protection of Workers/Laborers and Business Continuity in Covid-19 Prevention and Control Framework. In this Circular Letter of the Minister of Manpower (Menaker), it can be seen in statement number II point 4 which explains that companies affected by restrictions on business activities are due to government policies in the context of overcoming and preventing Covid-19 which results in workers not coming to work, with consideration for the operation of the business, the method of payment or changes in the amount of workers' wages is carried out on the basis of an agreement between the employer and the worker (JDIH Kemnaker, 2020) Menaker Ida Fauziah issued this letter with the consideration of taking steps to protect workers and the continuity of the business (prfmnews.id, 2 May 2020). 


\section{Conclusion}

Legal protection for workers as well as provisions for deducting workers' wages are clearly regulated in Law no. 13 of 2003, PP. 78 of 2015, and the Minister of Manpower's Circular Letter No. M/3/HK.04/III/2020. Unfortunately, it is a fact that occurs in society, some companies do not follow the applicable regulations and prefer to violate workers' rights. The imposition of sanctions against companies that violate the rights of workers is regulated in the applicable laws and regulations. However, in the midst of the Covid-19 pandemic, the government through the Minister of Manpower stated that there were no sanctions that could be given to the company seeing that the current situation was considered abnormal, and the administrative sanctions stipulated in legislation were sanctions that were given when conditions were normal. Thus, the government guarantees the fulfillment of workers' rights and has played an active role in helping to resolve cases of unilaterally cutting workers' wages either by means of bailouting the payment of wages for workers to regain their rights, as well as as a mediator in negotiations between the company and workers to achieve justice and legal protection for workers' rights.

\section{References}

Accurate.partners. (2020, April 14). Dampak Serta Ancaman COVID-19 Bagi Pekerja dan Perusahaan. Retrieved from Accurate Digital Partner News: https://accurate.partners/news/dampak-sertaancaman-covid-19-bagi-pekerja-dan-perusahaan/

Anwar, M. (2020). Dilema PHK dan Potong Gaji Pekerja. 'Adalah: Buletin Hukum dan Keadilan, Vol. 4, No. 1, 173-178.

Badrulzaman, Mariam Darus. 1983. KUH Perdata Buku III:Hukum Perikatan dengan Penjelasa. Alumni.

cnnindonesia.com. (2020, Maret 12). WHO Umumkan Virus Corona Sebagai Pandemi. Retrieved from CNNIndonesia: https://www.cnnindonesia.com/internasional/20200312000124-134-482676/whoumumkan-virus-corona-sebagai-pandemi

detiknews.com. (2020, Maret 24). Buruh Pabrik Pakaian Dalam di Magetan Demo Gegara Gajinya Belum Dibayar.Retrieved from Detik News: https://news.detik.com/berita-jawa-timur/d4952084/buruh-pabrik-pakaian-dalam-di-magetan-demo-gegara-gajinya-belum-dibayar

finance.detik.com. (2020, April 2). Pengusaha Potong Gaji Karyawan di Tengah Corona, Ini Kata Kemnaker. Retrieved from Detik Finance: https://finance.detik.com/berita-ekonomi-bisnis/d4962608/pengusaha-potong-gaji-karyawan-di-tengah-corona-ini-kata-kemnaker

Gubernur DKI Jakarta . (2020, Maret 20). Seruan Gubernur Daerah Khusus Ibukota Jakarta Nomor 6 Tahun 2020 Tentang Penghentian Sementara Kegiatan Perkantoran Dalam Rangka Mencegah Penyebaran Wabah Coronavirus Disease (Covid-19). Retrieved from JDIH Jakarta: https://jdih.jakarta.go.id/uploads/default/produkhukum/SE_Gub_No.6_Tahun_2020.pdf

Harnowo, Tri. 2020. Wabah corona sebagai alasan Force Majeure dalam perjanjian. March 30. https://www.hukumonline.com/klinik/detail/ulasan/lt5e81ae9a6fc45/wabah-corona-sebagaialasan-iforce-majeur-i-dalam-perjanjian/.

Hua,J.,\&Shaw,R.(2020).Corona Virus(COVID-19)“Infodemic”and Emerging Issues through a Data Lens: The Case of China. International Journal of Environmental Research and Public Health,1-12.

Huwaida, N. N. (2020). Sumber - Sumber Pembiayaan Dari Pemerintah Dan Masyarakat Selama Pandemi Coronavirus Disease (COVID 19). Retrieved from cloudfront.net .

Indonesia, Undang Undang Republik.2003."Nomor 13 Tahun 2003 Tentang Ketenagakerjaan." Pasal 104. 
Isradjuningtyas, Agri Chairunisa. 2015. "Force Majeure (Overmacht) Dalam Hukum Kontrak (Perjanjian)." Jurnal.Unpar.ac.id 5.

Kitab Undang Undang Hukum Perdata. n.d. "Buku Ketiga Perikatan nomor 3 tahun 1947." Pasal 1320.

Kompas.com. (2020, Maret 29). Daftar Wilayah di Indonesia yang Terapkan "Local Lockdown". Retrieved from Kompas: https://www.kompas.com/tren/read/2020/03/29/083900665/daftarwilayah-di-indonesia-yang-terapkan-local-lockdown-?page=all

Kompas.com. (2020, Maret 25). Pabrik Pakaian Dalam di Magetan Potong Gaji 50 Persen dengan Alasan Corona, Ribuan Karyawan Demo. Retrieved from Kompas: https://regional.kompas.com/read/2020/03/25/09334371/pabrik-pakaian-dalam-di-magetanpotong-gaji-50-persen-dengan-alasan-corona?page=all

Kompas.com. (2020, Maret 25). Pemkab Magetan Talangi Gaji Ribuan Karyawan Pabrik Pakaian Dalam yang Demo Upah Dipotong Sepihak Akibat Corona. Retrieved from Kompas: https://regional.kompas.com/read/2020/03/25/12113501/pemkab-magetan-talangi-gaji-ribuankaryawan-pabrik-pakaian-dalam-yang-demo?page=all

Kompas.com. (2020, Maret 12). Timeline Wabah Virus Corona, Terdeteksi pada Desember 2019 hingga Jadi Pandemi Global. Retrieved from Kompas: https://www.kompas.com/tren/read/2020/03/12/113008565/timeline-wabah-virus-coronaterdeteksi-pada-desember-2019-hinggajadi?page=all\#: :text=14\%20Februari\%202020\&text=Di\%20hari\%20yang\%20sama\%2C\%20pe merintah,di\%20Afrika\%20sejak\%20virus\%20terdeteksi.

Maderendika. 2019 . Hak-Hak Perusahaan dan Karyawan dalam Undang-Undang Ketenagakerjaan. January 13. https://sleekr.co/blog/hak-perusahaan-dan-karyawan-dalam-undang-undangketenagakerjaan/.

Menteri Ketenagakerjaan Republik Indonesia. (2020, Maret 17). SURAT EDARAN MENAKER NO M/3/HK.04/III/2020 Tentang Perlindungan Pekerja/Buruh Dan Kelangsungan Usaha Dalam Rangka Pencegahan Dan Penanggulangan COVID-19. Retrieved from JDIH Kemnaker: https://jdih.kemnaker.go.id/data_puu/SE_Pelindungan_Pekerja.pdf

Muhammad, Abdulkadir. 2010. "Hukum Perusahaan Indonesia." Citra Aditya.

Nasution, B. J. (2014). Kajian Filosofis Tentang Konsep Keadilan Dari Pemikiran Klasik Sampai Pemikiran Modern. Yustisia Vol. 3 No.2, 118-130.

Nola, L. F. (2016). Upaya Pelindungan Hukum Secara Terpadu Bagi Tenaga Kerja Indonesia (Tki). Negara Hukum: Vol. 7, No. 1, 35-52.

nusadaily.com. (2020, Maret 25). Karyawan Pabrik Pakaian Dalam Magetan Gelar Aksi Demo Pembayaran Gaji. Retrieved from Nusa Daily: https://nusadaily.com/jatim/karyawan-pabrikpakaian-dalam-magetan-gelar-aksi-demo-pembayaran-gaji.html

Presiden Republik Indonesia . (2003, Maret 25). Undang-Undang Republik Indonesia Nomor 13 Tahun 2003 Tentang Ketenagakerjaan. Retrieved from JDIH BPK RI: https://peraturan.bpk.go.id/Home/Details/43013

Presiden Republik Indonesia. (2020, Oktober 23). Peraturan Pemerintah Republik Indonesia Nomor 78 Tahun 2015 Tentang Pengupahan. Retrieved from JDIH Kemnaker: https://jdih.kemnaker.go.id/data_puu/PP_Nomor_78_Tahun_2015(1).pdf 
prfmnews.id. (2020, Mei 2). Sudah Tahu Ketentuan Gaji Karyawan Saat Pandemi Covid-19? Berikut Rinciannya. Retrieved from PRFM News: https://prfmnews.pikiran-rakyat.com/nasional/pr13375120/sudah-tahu-ketentuan-gaji-karyawan-saat-pandemi-covid-19-berikut-rincianny

Rachmadsyah, Shanti. 2010. Hukum Perjanjian. August 3. https://www.hukumonline.com/klinik/detail/ulasan/lt4c3d1e98bb1bc/hukum-perjanjian/.

Rasuh, Daryl John. February 2016. "Kajian Hukum Keadaan Memaksa (Force Majeure) Menurut Pasal 1244 Dan Pasal 1245 Kitab Undang-Undang Hukum Perdata ,/Feb/2016." Lex Privatum Vol. IV/No. 22.

Redaksi Kumparan. 2020. Kumparan. March 30. https://kumparan.com/kumparannews/arti-psbb-yangditetapkan-jokowi-dan-perbedaan-dengan-lockdown-1t7s6Hq9P7k/full.

Sonata, D. L. (2014). Metode Penelitian Hukum Normatif dan Empiris: Karakteristik Khas dari Metode Meneliti Hukum. Fiat Justisia Jurnal Ilmu Hukum Volume 8 No. 1, 15-35.

Tim Detikcon. 2020. Detik News. March 28. https://news.detik.com/berita/d-4956298/daftar-negara-yanglockdown-karena-corona.

Taufik, \& Ayuningtyas, E. A. (2020). Dampak Pandemi Covid-19 Terhadap Bisnis Dan Eksistensi Platform Online. Jurnal Pengembangan Wiraswasta Vol. 22 No. 01, 21-32.

tribunstyle.com. (2020, Maret 25). Gara-gara Corona, Pabrik di Magetan Potong Gaji 50\%, Ribuan Karyawan Demo \& Pecahkan Kaca Mobil. Retrieved from Tribun Style: https://style.tribunnews.com/amp/2020/03/25/gara-gara-corona-pabrik-di-magetan-potong-gaji50-ribuan-karyawan-demo-pecahkan-kaca-mobil

\section{UNDANG-UNDANG. NOMOR 3 TAHUN 1982. "TENTANG WAJIB DAFTAR PERUSAHAAN."}

voaindonesia.com. (2020, Agustus 10). Pemotongan Gaji Hingga PHK Sepihak, Industri Media Terseokseok di Tengah Pandemi. Retrieved from VOA Indonesia: https://www.voaindonesia.com/a/pemotongan-gaji-hingga-phk-sepihak-industri-media-terseokseok-di-tengah-pandemi/5536743.html

Wanda Ayu. 2020. Universitas Indonesia. March 26. https://www.ui.ac.id/rektor-ui-memahami-dampaklockdown-bagi-perekonomian-indonesia/.

Wati, S. A., Budiono, A. R., \& Hitaningtyas , R. D. (2015). Kajian Yuridis Pasal 93 Ayat (2) Huruf F Undang-Undang Nomor 13 Tahun 2003 Tentang Ketenagakerjaan Dikaitkan Dengan Kewenangan Absolut Pengadilan Hubungan Industrial. Jurnal Hukum.

WHO. 2020. World Healt Organisation. April 27. https://www.who.int/news-room/detail/27-04-2020who-timeline---covid-19.

\section{Copyrights}

Copyright for this article is retained by the author(s), with first publication rights granted to the journal.

This is an open-access article distributed under the terms and conditions of the Creative Commons Attribution license (http://creativecommons.org/licenses/by/4.0/). 